\title{
The Response of Muscle Protein Anabolism to Combined Hyperaminoacidemia and Glucose-Induced Hyperinsulinemia Is Impaired in the Elderly
}

\author{
ELENA VOLPI ${ }^{\dagger}$, BETTINA MITTENDORFER, BLAKE B. RASMUSSEN, and ROBERT R. \\ WOLFE \\ Departments of Internal Medicine (E.V.), Surgery (B.M., B.B.R., R.R.W.), and Anesthesiology \\ (R.R.W.), University of Texas Medical Branch, and Shriners Hospital (E.V., B.M., B.B.R., R.R.W.), \\ Galveston, Texas 77550
}

\begin{abstract}
Muscle mass declines with aging. Amino acids alone stimulate muscle protein synthesis in the elderly. However, mixed nutritional supplementation failed to improve muscle mass. We hypothesized that the failure of nutritional supplements is due to altered responsiveness of muscle protein anabolism to increased amino acid availability associated with endogenous hyperinsulinemia.

We measured muscle protein synthesis and breakdown, and amino acid transport in healthy young ( $30 \pm 3 \mathrm{yr}$ ) and elderly ( $72 \pm 1 \mathrm{yr}$ ) volunteers in the basal postabsorptive state and during the administration of an amino acid-glucose mixture, using $\mathrm{L}_{\mathrm{L}}\left[\right.$ ring- ${ }^{2} \mathrm{H}_{5}$ ]phenylalanine infusion, femoral artery and vein catheterization, and muscle biopsies. Basal muscle amino acid turnover was similar in young and elderly subjects. The mixture increased phenylalanine leg delivery and transport into the muscle in both groups. Phenylalanine net balance increased in both groups (young, $-27 \pm 8$ to $64 \pm 17$; elderly, $-16 \pm 4$ to $29 \pm 7 \mathrm{nmol} /(\mathrm{min} \cdot 100 \mathrm{~mL}$ ); $P<0.0001$, basal vs. mixture), but the increase was significantly blunted in the elderly $(P=0.030 v s$. young). Muscle protein synthesis increased in the young, but remained unchanged in the elderly [young, $61 \pm 17$ to $133 \pm 30(P=0.005)$; elderly, $62 \pm 9$ to $70 \pm 14 \mathrm{nmol} /(\mathrm{min} \cdot 100 \mathrm{~mL})(P=\mathrm{NS})]$. In both groups, protein breakdown decreased $(P=0.012)$ and leg glucose uptake increased $(P=0.0258)$ with the mixture.

We conclude that the response of muscle protein anabolism to hyperaminoacidemia with endogenous hyperinsulinemia is impaired in healthy elderly due to the unresponsiveness of protein synthesis.
\end{abstract}

\footnotetext{
Muscle mass and function progressively decline with aging $(1,2)$. This process has been termed sarcopenia and is associated with risk of falls and functional dependence $(3,4)$. Both undernutrition and disuse have been identified as potentially preventable contributing factors $(5,6)$. Nutritional intervention is an appealing method of prevention and treatment of sarcopenia of the elderly due to its wide applicability and safety. However, attempts to
}

\footnotetext{
Copyright $(9) 2000$ by The Endocrine Society

Address all correspondence and requests for reprints to: Elena Volpi, M.D., Ph.D., Department of Medicine, Division of Endocrinology, University of Southern California, 1333 San Pablo Street, BMT-B11, Los Angeles, California 90033. ${ }^{\dagger}$ Recipient of the Brookdale National Fellowship.

* This work was supported by NIH Grant AG-15780 and NIH Claude D. Pepper Older Americans Independence Center Grant P60AG-17231. It was conducted at the General Clinical Research Center, University of Texas Medical Branch (Galveston, TX), funded by Grant M01-RR-00073 from the National Center for Research Resources, NIH, USPHS.
} 
improve muscle mass and strength in the elderly with nutritional supplements failed to demonstrate a beneficial effect $(7,8)$.

The failure of nutritional supplementation in the treatment of sarcopenia of the elderly may be due to age-related alterations of muscle protein metabolism in response to feeding. This hypothesis is indirectly supported by recent data in humans suggesting that protein requirements increase with age (9). Increased protein requirements in aging suggest a decline in the ability of old muscle to use and maintain dietary amino acids. Recent studies in old rats have shown that muscle protein synthesis is blunted during balanced feeding (10). In humans, muscle protein synthesis has been found to be slower in elderly compared with young controls during a 5-h meal (11). However, when these data were compared with those obtained in different subjects in the fasting state the stimulation of muscle protein synthesis from the basal level appeared to be similar in elderly and young (11). On the other hand, another study from the same group showed that high protein meals do not stimulate muscle protein synthesis in elderly volunteers undergoing exercise training (12). Nevertheless, we recently reported that muscle protein turnover is similar in healthy elderly to that in younger counterparts in the fasting state and in response to an amino acid load $(13,14)$. Our results appear to be in conflict with those of other investigators $(7,8,10,12)$, although this is not necessarily the case, as different combinations of nutrients were used. We used a balanced mixture of amino acids alone $(13,14)$, whereas all other studies $(7,8,10,12)$ used a mixture of protein, fat, and carbohydrate, which stimulated the endogenous insulin response.

Like amino acids, insulin is a very potent anabolic stimulus for muscle protein metabolism. Different researchers have shown that in young adults insulin stimulates muscle protein anabolism when given alone or in combination with amino acids, and that the combination of insulin and amino acids appears to be more beneficial than either stimulus alone in young individuals (reviewed in Ref. 15). Although the mechanism(s) is still under debate (16), aging is associated with increased prevalence of insulin resistance that results in glucose intolerance and diabetes (17). However, no data are available on the physiologic interaction between amino acids and insulin on muscle protein metabolism in the elderly.

Based on prior studies, we hypothesized that the failure of mixed nutritional supplementation to increase muscle mass in the elderly depends on specific alterations in the response of muscle to the combined effects of exogenous amino acids and endogenous insulin. Consequently, we compared in healthy young and elderly subjects the response of muscle protein synthesis, breakdown and net balance to ingestion of a mixture of amino acids and glucose that stimulates endogenous hyperinsulinemia.

\section{Subjects and Methods}

\section{Subjects}

We recruited five healthy young (one woman and four men; age, $30 \pm 3 \mathrm{yr}$; body mass index, $24.7 \pm 0.4 \mathrm{~kg} / \mathrm{m}^{2}$ ) and five healthy elderly (one woman and four men; age, $72 \pm 1 \mathrm{yr}$; body mass index, $25.9 \pm 0.9 \mathrm{~kg} / \mathrm{m}^{2}$ ) volunteers through the Center on Aging Volunteers Registry of the University of Texas Medical Branch. All subjects gave informed written consent before participating in the study, which was approved by the Institutional Review Board of the University of Texas Medical Branch (Galveston, TX).

Volunteer eligibility was assessed by physical examination and laboratory tests, including electrocardiogram, blood count, plasma electrolytes, liver and renal function tests, blood glucose, and oral glucose tolerance test. Exclusion criteria were heart disease, coagulation disorders, artery or vein diseases, hypertension, obesity, cancer, acute or chronic pulmonary diseases, infectious diseases, and diabetes mellitus or glucose intolerance, as defined by the 
report of the Expert Committee on the Diagnosis and Classification of Diabetes Mellitus (18).

Both young and elderly volunteers were physically active, i.e. living on their own with no limitation in ambulation or history of falls, although not exercise trained. We specifically excluded subjects of any age who were engaged in exercise training programs.

\section{Study design}

Each subject was studied after an overnight fast. The volunteers were instructed to eat their usual diet during the week preceding the study to avoid metabolic changes due to recent dietary modifications. The evening before the study the subjects were admitted to the General Clinical Research Center of the University of Texas Medical Branch. They ate a light dinner, after which they were allowed only water ad libitum. The morning of the study, at approximately $0600 \mathrm{~h}$, polyethylene catheters were inserted into a forearm vein for tracer infusion, in the wrist vein of the opposite hand for arterialized blood sampling, and in the femoral artery and vein of one leg for blood sampling. The arterial catheter was also used for the infusion of indocyanine green (ICG; Cardio-Green, Becton Dickinson and Co., Cockeysville, MD).

After a blood sample was drawn for the measurement of background phenylalanine and glucose enrichments and ICG concentration, a primed continuous infusion of $\mathrm{L}_{-}$ [ring- ${ }^{2} \mathrm{H}_{5}$ ]phenylalanine (priming dose, $2 \mu \mathrm{mol} / \mathrm{kg}$; infusion rate, $0.05 \mu \mathrm{mol} /(\mathrm{kg} \cdot \mathrm{min}$ ); Cambridge Isotope Laboratories, Andover, MA) and [6,6- $\left.{ }^{2} \mathrm{H}_{2}\right]$ glucose (priming dose, 19 $\mu \mathrm{mol} / \mathrm{kg}$; infusion rate, $0.22 \mu \mathrm{mol} /(\mathrm{kg} \cdot \mathrm{min})$; Cambridge Isotope Laboratories) were started and maintained at constant rate for 480 min until the end of the experiment (Fig. 1). At 120 min a muscle biopsy was taken from the lateral portion of the muscle vastus lateralis of the leg with the femoral catheters, about $20 \mathrm{~cm}$ above the knee, using a 5-mm Bergström biopsy needle. The tissue was immediately frozen in liquid nitrogen and stored at $-80 \mathrm{C}$ until analysis. At $230 \mathrm{~min}$ a continuous infusion of ICG dye $(0.5 \mathrm{mg} / \mathrm{min})$ was started in the femoral artery and was maintained until $270 \mathrm{~min}$ to measure leg blood flow. To measure the plasma ICG concentration, four blood samples were taken every 10 min between 240-270 min from the femoral and wrist veins. Subsequently, between 270-300 min, four blood samples were taken every $10 \mathrm{~min}$ from the femoral artery and vein to measure plasma phenylalanine concentrations and enrichments, and glucose concentration. At 240 and 300 min additional blood samples were drawn from the femoral artery to measure insulin, $\mathrm{GH}$, and insulin-like growth factor I (IGF-I) concentrations. At 300 min a second muscle biopsy was taken as previously described. Immediately after the biopsy was taken, oral administration of a liquid amino acid-glucose mixture was started and continued for $3 \mathrm{~h}$ until the end of the study. The mixture contained a total of $40 \mathrm{~g}$ glucose and $40 \mathrm{~g}$ crystalline amino acids (Sigma, St. Louis, MO) in the same proportion as that found in beef proteins (19). The mixture was dissolved in $540 \mathrm{~mL}$ water containing a sugar-free flavoring (Crystal Light, Kraft Foods, Inc., White Plains, NY). The mixture was given as small boluses (30 $\mathrm{mL}$ ) every $10 \mathrm{~min}$ to achieve steady state plasma phenylalanine enrichments and concentrations, and steady state blood glucose concentrations. The amount of glucose (young, $17.83 \pm 0.15$; elderly, $18.04 \pm 0.33 \mathrm{mg} /(\mathrm{kg} \cdot \mathrm{min}$ ); $P=0.57$ ), phenylalanine (young, $0.75 \pm 0.03$; elderly, $0.73 \pm 0.05 \mu \mathrm{mol} /(\mathrm{kg} \cdot \mathrm{min}$ ); $P=0.70$ ), and total amino acids (young, $3.08 \pm 0.12$; elderly, $2.95 \pm 0.22 \mathrm{mg} /(\mathrm{kg} \cdot \mathrm{min}) ; P=0.64)$ given were similar in the two groups. To avoid an excessive reduction of blood glucose enrichment during oral glucose intake, the infusion rate of $\left[6,6-{ }^{2} \mathrm{H}_{2}\right]$ glucose was increased to $0.85 \mu \mathrm{mol} /(\mathrm{kg} \cdot \mathrm{min})$. We chose to increase the iv infusion of labeled glucose rather than add the tracer to the oral mixture because the oral glucose was given at a constant rate, and therefore the problem of isotopic nonsteady state was not an issue. Between 420 and $480 \mathrm{~min}$ the measurement of leg blood flow was repeated, and blood samples were taken as described for the fasting period. At 480 
min, before stopping the tracer and amino acid infusion, a third muscle biopsy was taken. All of the subjects but one young volunteer, who was lost at follow-up, underwent leg magnetic resonance imaging (MRI) to measure muscle leg volume approximately $1-2$ weeks after the study.

\section{Analytical methods}

The concentration of plasma insulin was measured with a commercial RIA kit (Diagnostic Products, Los Angeles, CA). Plasma human (h) GH was measured using a commercial immunoassay (Nichols Institute Diagnostics, San Juan Capistrano, CA), and IGF-I was measured using a commercial immunoradiometric assay (Nichols Institute Diagnostics, San Juan Capistrano, CA). Plasma glucose concentrations were measured with an enzymatic method (YSI, Inc., Yellow Springs, OH). The serum ICG concentration was measured with a spectrophotometer set at $\lambda=805 \mathrm{~nm}$.

The arterial and venous samples were processed as previously described (20), and phenylalanine and glucose enrichments and phenylalanine concentrations were measured using gas chromatography-mass spectrometry (GCMS; GC HP 5890, MSD HP 5989, Hewlett-Packard Co., Palo Alto, CA).

Muscle samples were processed as previously described (20), and free tissue phenylalanine enrichments and concentrations were determined by GCMS. The intracellular concentration of phenylalanine was then calculated from the tissue value, accounting for the ratio of intracellular to extracellular water (21). Mixed muscle protein-bound phenylalanine enrichment was measured by GCMS (GC 8000 series, MD 800, Fisons Instruments, Manchester, UK) using the standard curve approach previously described (22).

Leg skeletal muscle volume was determined by analysis of images collected by MRI (GE Signa 1.5 Tesla whole body imager: General Electric, Milwaukee, WI). Initial images were taken of the frontal plane to establish the anatomical landmarks used to demarcate upper (greater trochanter to patella) and lower (patella to ankle) leg series. Consecutive transaxial images, $10 \mathrm{~mm}$ thick, were collected between these landmarks. The differences between fat (200-300 ms) and muscle (800-900 ms) relaxation times in T1 enabled analysis using an intensity threshold method. The images were subsequently processed using NIH Image software (NIH public domain analysis package).

\section{Calculations}

We calculated skeletal muscle amino acid kinetics from the enrichments and concentrations of phenylalanine in the femoral artery and vein and from the enrichment of tissue-free phenylalanine, using a three-pool model previously described and validated (21).

Phenylalanine was used because it is an essential amino acid, i.e. it is not produced in the body and is not oxidized in the muscle tissue. Thus, it allows calculation of muscle protein synthesis and breakdown in addition to the measurement of amino acid delivery to the leg, release from the leg, transport into and from the muscle tissue, and shunting from the artery to the vein without entering the tissue space. The three-pool model parameters were calculated as follows: delivery to the leg, $\mathrm{F}_{\text {in }}=\mathrm{C}_{\mathrm{A}} \times \mathrm{BF}(\mathrm{Eq} \mathrm{I})$; release from the leg, $\mathrm{F}_{\text {out }}=$ $\mathrm{C}_{\mathrm{V}} \times \mathrm{BF}\left(\mathrm{Eq}\right.$ II); net balance across the leg, $\mathrm{NB}=\left(\mathrm{C}_{\mathrm{A}}-\mathrm{C}_{\mathrm{V}}\right) \times \mathrm{BF}(\mathrm{Eq}$ III); transport into muscle, $\mathrm{F}_{\mathrm{M}, \mathrm{A}}=\left\{\left[\left(\mathrm{E}_{\mathrm{M}}-\mathrm{E}_{\mathrm{V}}\right) /\left(\mathrm{E}_{\mathrm{A}}-\mathrm{E}_{\mathrm{M}}\right) \times \mathrm{C}_{\mathrm{V}}\right]+\mathrm{C}_{\mathrm{A}}\right\} \times \mathrm{BF}(\mathrm{Eq} \mathrm{IV})$; transport from muscle, $\mathrm{F}_{\mathrm{V}, \mathrm{M}}=\left\{\left[\left(\mathrm{E}_{\mathrm{M}}-\mathrm{E}_{\mathrm{V}}\right) /\left(\mathrm{E}_{\mathrm{A}}-\mathrm{E}_{\mathrm{M}}\right) \times \mathrm{C}_{\mathrm{V}}\right]+\mathrm{C}_{\mathrm{V}}\right\} \times \mathrm{BF}(\mathrm{Eq} \mathrm{V})$; artery-vein shunting, $\mathrm{F}_{\mathrm{V}, \mathrm{A}}=\mathrm{F}_{\text {in }}$ $-\mathrm{F}_{\mathrm{M}, \mathrm{A}}(\mathrm{Eq} \mathrm{VI})$; muscle protein breakdown, $\mathrm{F}_{\mathrm{M}, \mathrm{O}}=\mathrm{F}_{\mathrm{M}, \mathrm{A}} \times\left[\left(\mathrm{E}_{\mathrm{A}} / \mathrm{E}_{\mathrm{M}}\right)-1\right](\mathrm{Eq} \mathrm{VII}) ;$ and muscle protein synthesis, $\mathrm{F}_{\mathrm{O}, \mathrm{M}}=\mathrm{F}_{\mathrm{M}, \mathrm{O}}+\mathrm{NB}$ (Eq VIII). $\mathrm{C}_{\mathrm{A}}$ and $\mathrm{C}_{\mathrm{V}}$ are plasma phenylalanine concentrations in the femoral artery and vein, respectively; $\mathrm{E}_{\mathrm{A}}, \mathrm{E}_{\mathrm{V}}$, and $\mathrm{E}_{\mathrm{M}}$ are phenylalanine enrichments (tracer/tracee ratio) in femoral arterial and venous plasma and 
in muscle, respectively; BF is leg blood flow. Data are presented per $100 \mathrm{~mL}$ leg volume (21).

Leg plasma flow was calculated from the steady state dye concentration values in the femoral and wrist vein as previously described $(23,24)$. Leg blood flow was calculated by correcting the plasma flow by the hematocrit.

Additionally, we determined the fractional synthetic rate (FSR) of mixed muscle proteins by measuring the incorporation rate of ${ }_{\mathrm{L}}\left[\right.$ ring $\left._{-}{ }^{2} \mathrm{H}_{5}\right]$ phenylalanine into the proteins using the precursor-product model (25) as follows: $\left.\mathrm{FSR}=\left\{\left[\left(\Delta \mathrm{E}_{\mathrm{P}} / t\right) /\right]\left(\mathrm{E}_{\mathrm{M}(1)}+\mathrm{E}_{\mathrm{M}(2)}\right) / 2\right]\right\} \times 60 \times 100$ (Eq IX). $\Delta \mathrm{E}_{\mathrm{P}}$ is the increment in protein-bound phenylalanine enrichment between two sequential biopsies, $t$ is the time interval between the two sequential biopsies, and $\mathrm{E}_{\mathrm{M}(1)}$ and $\mathrm{E}_{\mathrm{M}(2)}$ are the phenylalanine enrichments (tracer/tracee ratio) in the free muscle pool in the two subsequent biopsies. The results are presented as the percentage per hour.

Glucose delivery to the leg, release from the leg, and uptake across the leg were calculated as follows: glucose delivery $=\mathrm{G}_{\mathrm{A}} \times \mathrm{BF}(\mathrm{Eq} \mathrm{X})$, glucose release $=\mathrm{G}_{\mathrm{V}} \times \mathrm{BF}(\mathrm{Eq} \mathrm{XI})$, and glucose uptake $=\left(\mathrm{G}_{\mathrm{A}}-\mathrm{G}_{\mathrm{V}}\right) \times \mathrm{BF}(\mathrm{Eq}$ XII $) . \mathrm{G}_{\mathrm{A}}$ and $\mathrm{G}_{\mathrm{V}}$ are the blood glucose concentrations in the femoral artery and vein, respectively.

The whole body glucose rate of appearance $(\mathrm{Ra})$ was calculated using the single pool model as follows (26): glucose $\mathrm{Ra}=\mathrm{I} / \mathrm{E}_{\mathrm{A}}(\mathrm{Eq} \mathrm{XIII}) . \mathrm{E}_{\mathrm{A}}$ the arterial glucose enrichment, and $\mathrm{I}$ is the tracer infusion rate. During the intake of the oral amino acid-glucose mixture, the above formula represented the total glucose $\mathrm{Ra}$, i.e. endogenous plus exogenous glucose $\mathrm{Ra}$. Therefore, during oral glucose intake endogenous glucose Ra was calculated by subtracting the oral glucose administration rate from the total $\mathrm{Ra}$, assuming that all of the oral glucose was absorbed: endogenous glucose $\mathrm{Ra}=$ total glucose $\mathrm{Ra}-$ oral glucose intake (Eq IV).

\section{Statistical analysis}

The effect of age on the response variables in the fasting state and during infusion of the amino acid-glucose mixture was analyzed using two-way ANOVA with repeated measures. Post-hoc pairwise multiple comparisons were carried out when appropriate using the $t$ test modified with Bonferroni's correction. Differences were considered significant at $P<0.05$. Data are presented as the mean \pm SE.

\section{Results}

\section{Leg and muscle volume}

Total leg volume was slightly, but not significantly, lower in the elderly (young, $10.17 \pm$ 0.45 ; elderly, $9.16 \pm 0.58 \mathrm{~L} ; P=0.21)$. Similarly, leg muscle volume was slightly, but not significantly, lower in the elderly $(n=5)$ compared with the young $(n=4$, one volunteer did not undergo the measurement) using total volume (young, $5.6 \pm 0.9$; elderly, $4.5 \pm 0.5 \mathrm{~L} ; \mathrm{P}=$ 0.34 ), percent leg volume (young, $48 \pm 5 \%$; elderly, $45 \pm 4 \% ; P=0.60$ ), or muscle volume corrected by the squared height to obtain a leg muscle index (young, $1.86 \pm 0.25$; elderly, $\left.1.52 \pm 0.1 \mathrm{~L} / \mathrm{m}^{2} ; P=0.29\right)$.

\section{Blood flow}

Leg blood flow was similar in young and elderly in the basal state [young, $3.38 \pm 0.49$; elderly, $3.82 \pm 0.58 \mathrm{~mL} /(\mathrm{min} \cdot 100 \mathrm{~mL} \mathrm{leg})]$. During amino acid-glucose intake, leg blood flow slightly increased in the young, whereas it decreased in the elderly [young, $4.31 \pm 0.79$; elderly, $2.99 \pm 0.54 \mathrm{~mL} /(\mathrm{min} \cdot 100 \mathrm{~mL}$ leg $)$ ], with a significant treatment by group interaction $(P=0.0178)$. 


\section{Hormones}

Arterial insulin concentrations were similar in young and elderly in the basal state, and increased significantly during amino acid-glucose intake $(P<0.0001$, basal $v s$. amino acidglucose mixture) with no differences between the groups (Table 1). Arterial hGH concentrations were slightly, but not significantly, lower in the elderly compared with those in the young during the basal period, and did not change significantly during administration of oral amino acids with glucose, although there was a trend in the young for a reduction in hGH concentrations with amino acid-glucose intake $(P=0.076)$ (Table 1). IGF-I concentrations were higher $(P=0.003)$ in the young than in the elderly both in the basal state and during administration of oral amino acids with glucose (Table 1). However, amino acid-glucose intake did not exert any effect on plasma IGF-I in either age group.

\section{Amino acid concentrations and enrichments}

Arterial essential amino acid concentrations were similar in the basal state in young and elderly and increased significantly and similarly in both groups during amino acid-glucose intake with the exception of tryptophan, which increased significantly only in the elderly, not in the young (Table 2). Nonessential amino acid concentrations were similar in the elderly and the young in the basal state with the exception of serine, which was lower in the elderly. The administration of oral amino acids with glucose significantly increased the concentrations of all nonessential amino acids except tyrosine, which did not change in either group. The increase in the concentrations of asparagine, histidine, and serine were blunted in the elderly (Table 2). Free phenylalanine concentrations in the femoral artery and vein were at steady state during the last hour of each study period (data not shown).

Phenylalanine concentrations in the femoral artery and vein and in the muscle tissue fluid were similar in the basal postabsorptive state in young and elderly (Table 3). During amino acid-glucose intake, the concentrations of free phenylalanine in the femoral artery and vein and in the muscle intracellular fluid significantly increased from the fasting values, with no differences between young and elderly. Plasma phenylalanine enrichments in the femoral artery and vein were at steady state during the last hour of the basal and amino acid-glucose periods in both groups (Fig. 2). In the basal state, phenylalanine enrichments in the femoral artery and vein were similar in the young and the elderly (Table 3). During amino acidglucose intake, phenylalanine enrichments decreased significantly in the femoral artery and vein. Tissue fluid enrichment (Table 3) was higher in the elderly in the basal state and decreased significantly during amino acid-glucose intake only in the elderly, with a significant treatment by group interaction $(P=0.0373)$.

\section{Muscle protein FSR}

Mixed muscle protein FSR was similar in the basal state in young and elderly (young, $0.0598 \pm 0.0087 \% / \mathrm{h}$; elderly, $0.0601 \pm 0.0110 \% / \mathrm{h}$ ). The amino acid-glucose mixture caused a significant increase in mixed muscle protein FSR only in the young $(P=0.029$, basal $v s$. amino acid-glucose mixture), whereas there was no change in the elderly (young, $0.0857 \pm$ $0.0119 \% / \mathrm{h}$; elderly, $0.0476 \pm 0.0153 \% / \mathrm{h} ; P=0.0241$, treatment by group interaction; Fig. $3)$.

\section{Amino acid kinetics across the leg}

The model-derived parameters of leg muscle free phenylalanine kinetics in the young and the elderly in the basal period (240-300 min) and during amino acid-glucose intake (420$480 \mathrm{~min}$ ) are reported in Table 4 . In the basal state, all of the model-derived parameters of free phenylalanine kinetics were similar in young and elderly. Amino acid-glucose intake significantly increased phenylalanine delivery to the leg and its release from the leg as well as phenylalanine transport into and from the muscle cells, with no differences between 
young and elderly. The rate at which phenylalanine was shunted from the artery to the vein did not change significantly in either young or elderly subjects. Muscle protein breakdown decreased significantly during amino acid-glucose intake in both groups. The tissue phenylalanine rate of appearance, calculated as the sum of inward transport and protein breakdown, was similar in the basal state [young, $172 \pm 24$; elderly, $209 \pm 17 \mathrm{nmol} /(\min \cdot 100$ $\mathrm{mL} / \mathrm{leg})]$ and increased $(P=0.019)$ similarly in the elderly and the young [young, $306 \pm 52$; elderly, $278 \pm 58 \mathrm{nmol} /(\mathrm{min} \cdot 100 \mathrm{~mL} / \mathrm{leg})]$. The rate of utilization of phenylalanine for protein synthesis increased significantly during amino acid-glucose intake only in the young, whereas there was no change in the elderly. This result was consistent with the FSR data. Phenylalanine net balance across the leg, which was negative in the fasting state, became positive during the intake of the amino acid-glucose mixture in both groups, indicating a shift from net protein breakdown to net protein synthesis. However, such an increase was blunted in the elderly.

\section{Glucose concentrations, enrichments, and turnover}

Blood glucose enrichments (Fig. 2) and concentrations (data not shown) were at steady state during the sampling hour of the basal and the amino acid-glucose study periods. The results of glucose kinetics are reported in Table 5 . Whole body glucose Ra, glucose delivery to the leg and release from the leg, and leg glucose uptake were similar in the basal state in the young and the elderly and increased significantly and similarly during amino acid-glucose intake. Endogenous glucose production decreased significantly and similarly in both young and elderly.

\section{Discussion}

Our data show that muscle protein anabolism is blunted in healthy elderly subjects during the intake of an amino acid-glucose mixture due to an impaired response of muscle protein synthesis. Such an alteration in protein kinetics was isolated, as the responses of both endogenous insulin and glucose kinetics to the amino acid-glucose mixture were similar in elderly and young.

In the young, we observed an increase in muscle protein anabolism in response to amino acid-glucose intake as indicated by the shift of phenylalanine net balance across the leg from a negative value, indicating net catabolism, to a positive value. The improvement in net balance was due to both increased protein synthesis and decreased protein breakdown. The results of protein synthesis are consistent with previous data from young subjects showing that hyperinsulinemia during hyperaminoacidemia stimulates muscle protein synthesis (27). As recent studies have shown that muscle protein breakdown is not decreased by the administration of amino acids alone in either the young or the elderly $(13,14,28)$, the reduction of muscle protein breakdown observed in the present study was probably caused by the glucose-induced hyperinsulinemia. The effect of insulin on muscle protein breakdown is still controversial; some of the studies show a reduction and others show no effect (reviewed in Ref. 15). It is possible that amino acid availability and/or the physiological conditions during the experiments play an important role in determining the response to insulin. Further investigations are required to clarify this issue.

In the elderly, the shift of net balance from negative to positive in response to amino acids with glucose was significantly blunted compared with that in the young controls. We considered the possibility that the apparent difference in net balance between elderly and young was due to the presentation of the data per unit of total leg volume. If the elderly had a reduced muscle volume relative to the total leg volume, the net balance per unit of total leg volume would be underestimated. Although we could not present our data per unit of muscle volume due to the fact that one volunteer could not undergo the leg MRI, we are convinced 
that this was not the case. In fact, the older volunteers in our study not only had a smaller muscle volume, but also had a smaller total leg volume, so that the muscle volume relative to the total leg volume was not different between elderly and young (45\% vs. $48 \%)$. In addition, changes in leg volume would linearly affect the values for both basal and amino acid-glucose periods, so that the magnitude of the response to the amino acid-glucose stimulus (i.e. the change over basal) would not be influenced.

The difference in muscle protein anabolism between elderly and young subjects was due to a lack of responsiveness of muscle protein synthesis (FSR and three-pool model) to the amino acid-glucose stimulus in the elderly. Thus, the net balance shift to a positive value during amino acid-glucose intake in the elderly was entirely due to a reduction in protein breakdown. These findings are surprising if we consider that we have shown in previous experiments that amino acids alone stimulate net muscle protein anabolism in the elderly, as in the young, by increasing protein synthesis in the absence of effects on breakdown (13, 14). One of the previous studies was performed by administering the same dose of amino acids given in the present experiment to comparable groups of young and elderly volunteers (14). This gave us the opportunity to compare the general effects of amino acids with glucose $v s$. amino acids alone on net muscle protein anabolism in young and elderly (Fig. 4). Whereas glucose increased the positive effect of amino acids in the young, phenylalanine net balance was slightly, but not significantly, higher during amino acid-glucose treatment compared with amino acid treatment alone in the elderly. Overall, these results suggest that whereas in young adults the addition of glucose to an amino acid mixture augments the effect of amino acids alone in stimulating muscle protein anabolism, such a combination in the elderly does not add a real benefit compared with that of amino acids alone. In fact, the addition of carbohydrate may even be detrimental, as the added carbohydrate reduces protein turnover by inhibiting protein breakdown and preventing the stimulatory effect of amino acids on protein synthesis, thereby reducing muscle tissue remodeling.

Such an alteration in the response of muscle protein synthesis to amino acids with glucose in the elderly was not due to reduced amino acid availability. The arterial concentrations of essential amino acids were similar in the elderly and the young during the basal state and during the oral intake of amino acids with glucose, with the exception of tryptophan, which was higher in the elderly. These findings allow us to exclude any possible role for differences in gastric emptying and/or splanchnic amino acid utilization, because if gastric emptying was reduced or splanchnic utilization was higher in the elderly, we should have observed a blunted response of arterial essential amino acid concentrations. In addition, the phenylalanine rate of appearance in muscle tissue, which is a measure of tissue amino acid availability, increased similarly in both age groups. The arterial concentrations of a few nonessential amino acids were lower in the elderly than in the young during amino acidglucose treatment. However, recent data indicate that nonessential amino acids are not necessary to stimulate muscle protein anabolism (29), suggesting that alterations in nonessential amino acid metabolism should not affect muscle protein turnover.

Glucose per se is an unlikely candidate for the observed negative effect of amino acidglucose on muscle protein synthesis in the elderly. If anything, the extra calories provided by glucose should have improved, not limited, the response of muscle protein synthesis.

As a direct effect of the administered substrates or differences in substrate availability could be safely excluded, we analyzed the possible role of the endogenous hormonal response on the surprisingly different response of muscle protein synthesis in the elderly.

Previous studies have shown that acute GH administration may $(30,31)$ or may not $(32,33)$ stimulate muscle protein synthesis. GH secretion is physiologically increased by amino 
acids and decreased by glucose administration, and it is generally reduced in older people (34). Assuming that GH directly stimulates muscle protein synthesis, a bigger suppression of GH secretion in the elderly compared with the young could have explained the differences in muscle protein synthesis between the two groups. However, we found that there was a trend for GH concentration to decrease during amino acid-glucose intake only in the young, whereas $\mathrm{GH}$ concentrations did not change from basal in the elderly.

On the other hand, consistent with previous data (35), we found that the IGF-I concentration was lower in the elderly than in the young. However, the IGF-I concentration did not change during amino acid-glucose intake in either the elderly or the young. If IGF-I had a role in the alteration of muscle protein synthesis during amino acid-glucose intake, we should have also observed differences in muscle protein synthesis both in the basal state and during the administration of amino acids alone $(13,14)$. This was not the case.

Thus, we hypothesize that the defect responsible for the age-related impairment of muscle protein synthesis during the intake of amino acids with glucose is due to an alteration in the response of muscle protein synthesis to the glucose-induced endogenous hyperinsulinemia. The finding that leg blood flow was reduced in the elderly during amino acid-glucose treatment is suggestive of an impaired response to insulin in the elderly, because normally insulin increases muscle blood flow (36-38). In fact, the altered response of blood flow observed in the present study is consistent with previous studies that found a paradoxical reduction of peripheral blood flow in the elderly during insulin infusion (39), as opposed to the vasodilatation observed in young adults (36-38). This may reflect a general response of insulin resistance, because previous studies have reported a similar alteration in the response of blood flow to insulin in type 2 diabetes patients $(40,41)$. Nonetheless, the impairment of the response of muscle protein synthesis to the intake of amino acids with glucose with aging is surprising, because the elderly volunteers in our study had normal glucose tolerance and insulin concentrations. In addition, whole body glucose turnover was similar in elderly and young subjects both in the basal state and during amino acid-glucose treatment, and muscle glucose uptake during the intake of amino acid-glucose was not different when comparing the elderly and the young subjects. This raises the possibility that a defect in the anabolic effect of insulin on muscle protein metabolism can develop in elderly individuals who retain the normal or quasi-normal responsiveness of muscle to the stimulatory effect of insulin on glucose uptake. This dichotomy is most likely due to the fact that glucose and protein metabolism are controlled by insulin through distinct intracellular signaling pathways, which can be independently affected by insulin resistance. This hypothesis is indirectly supported by a recent study showing that in conditions characterized by impaired glucose metabolism (obesity and type 2 diabetes) the signaling pathway affected by insulin resistance is the one controlling glucose metabolism (phosphatidylinositol 3-kinase), whereas the mitogen-activated protein kinase pathway, which is linked to cell growth and gene expression, appears to be normally responsive to insulin (42). As both insulin and amino acids stimulate protein synthesis using in part the same intracellular signaling pathways, specifically those that lead to the phosphorylation of the eukaryotic initiation factor 4E-binding protein-1 (43-47), it is possible that an age-related alteration in the responsiveness to insulin of one or more of these factors or enzymes may lead to the inhibition of the positive effects of amino acids on muscle protein synthesis. This speculation needs to be addressed in future studies.

Consistent with our previous data (14), basal protein turnover was similar in the elderly and the young. Several researchers have reported an age-related reduction in total muscle (48), myofibrillar $(11,49,50)$, or myosin heavy chain (51) protein synthesis rates, whereas others (52) and our laboratory (Ref. 14 and the present study) did not find any difference. As previously mentioned (14), the amount of daily physical activity performed by the 
volunteers might have played a role in the apparent discrepancy between our results and those previously reported. However, our elderly subjects were neither remarkably fit nor exercising regularly, and they had a slightly reduced muscle mass. Nonetheless, it is possible that undetectable differences in the activities of daily living might have been responsible for the discrepancies between our results and those in the literature. Modeling issues can be ruled out, because all of the studies used the same methodology, i.e. the tracer incorporation technique (FSR). In addition, in our studies the lack of a difference between young and elderly subjects in muscle protein synthesis rate was observed using either the three-pool model or the traditional labeled amino acid incorporation technique.

The lack of a difference in basal muscle protein synthesis between elderly and young subjects makes the results of the present study even more striking, suggesting that an altered response of muscle proteins to the combination of amino acids and glucose, with associated hyperinsulinemia, may be one of the mechanisms by which muscle mass is lost with aging, regardless of physical activity. Our results may also provide an explanation for the recent observation that protein requirements may increase with age $(8,9)$. Essential amino acids are physiologically replenished during the ingestion of proteins, usually occurring in the context of the ingestion of a meal containing carbohydrates. It is reasonable to assume that a diminished response of muscle amino acid utilization similar to that observed in this study occurs during a regular meal. If so, the lack of stimulation of muscle protein in response to a meal will probably contribute over the long term to a progressive loss of muscle.

Consequently, due to the diminished effectiveness of the amino acids absorbed after the ingestion of proteins eaten in the context of a mixed meal, additional protein intake is needed to achieve a protein balance. This explanation raises the question of the fate of the absorbed amino acids that are not incorporated into proteins. It is possible that these amino acids are oxidized, and the carbons excreted as $\mathrm{CO}_{2}$. In addition, the carbons from these amino acids could be routed through the lipogenic and/or gluconeogenic pathways. Indirect evidence supporting the utilization of dietary amino acids for fat synthesis when given in combination with carbohydrate comes from the study by Fiatarone et al. (7). They found that whereas mixed multinutritional supplements failed to increase muscle mass when given alone or in combination with exercise training (7), body weight nonetheless increased, suggesting that fat mass increased with the multinutrient supplement.

In conclusion, the results of this study show that muscle protein anabolism, but not glucose turnover, is impaired in healthy elderly volunteers during combined hyperaminoacidemia and endogenous hyperinsulinemia after the ingestion of amino acids with glucose due to the unresponsiveness of protein synthesis. This alteration is likely to contribute to the development, over the long term, of sarcopenia in the elderly.

\section{Acknowledgments}

We are indebted to Marilyn Brodwick, M.P.H., and James S. Goodwin, M.D., University of Texas Medical Branch, for their assistance in recruiting the volunteers for the study, and to Zhi Ping Dong, M.S., Shriners Hospital, for her technical assistance.

\section{References}

1. Evans WJ. What is sarcopenia? J Gerontol A Biol Sci Med Sci. 1995; 50:5-8. [PubMed: 7493218]

2. Lexell J. Human aging, muscle mass, and fiber type composition. J Gerontol. 1995; 50:11-16.

3. Wolfson L, Judge J, Whipple R, King M. Strength is a major factor in balance, gait, and the occurrence of falls. J Gerontol A Biol Sci Med Sci. 1995; 50:64-67. [PubMed: 7493221]

4. Tinetti ME, Williams CS. Falls, injuries due to falls, and the risk of admission to a nursing home. N Engl J Med. 1997; 337:1279-1284. [PubMed: 9345078] 
5. Roberts SB. Effects of aging on energy requirements and the control of food intake in men. J Gerontol A Biol Sci Med Sci. 1995; 50:101-106. [PubMed: 7493200]

6. Evans WJ. Exercise, nutrition and aging. J Nutr. 1992; 22(Suppl 3):796-801. [PubMed: 1542050]

7. Fiatarone MA, O'Neill EF, Ryan ND, et al. Exercise training and nutritional supplementation for physical frailty in very elderly people. N Engl J Med. 1994; 330:1769-1775. [PubMed: 8190152]

8. Campbell WW, Crim MC, Young VR, Joseph LJ, Evans WJ. Effects of resistance training and dietary protein intake on protein metabolism in older adults. Am J Physiol Endocrinol Metab. 1995; 268:E1143-E1153.

9. Pannemans DL, Wagenmakers AJ, Westerterp KR, Schaafsma G, Halliday D. Effect of protein source and quantity on protein metabolism in elderly women. Am J Clin Nutr. 1998; 68:1228-1235. [PubMed: 9846851]

10. Mosoni L, Valluy MC, Serrurier B, et al. Altered response of protein synthesis to nutritional state and endurance training in old rats. Am J Physiol. 1995; 268:E328-E335. [PubMed: 7864110]

11. Welle S, Thornton C, Statt M, McHenry B. Postprandial myofibrillar and whole body protein synthesis in young and old human subjects. Am J Physiol. 1994; 267:E599-E604. [PubMed: 7943310]

12. Welle $S$, Thornton CA. High-protein meals do not enhance myofibrillar synthesis after resistance exercise in 62- to 75-yr-old men and women. Am J Physiol. 1998; 274:E677-E683. [PubMed: 9575829]

13. Volpi E, Ferrando AA, Yeckel CW, Tipton KD, Wolfe RR. Exogenous amino acids stimulate net muscle protein synthesis in the elderly. J Clin Invest. 1998; 101:2000-2007. [PubMed: 9576765]

14. Volpi E, Mittendorfer B, Wolf SE, Wolfe RR. Oral amino acids stimulate muscle protein anabolism in the elderly despite higher first pass splanchnic extraction. Am J Physiol. 1999; 277:513-520.

15. Wolfe, RR.; Volpi, E. Insulin and protein metabolism. In: Jefferson, LS.; Cherrington, AD., editors. Handbook of physiology. Vol. 2. New York: Oxford University Press; 2000. p. 733-755.

16. Kohrt WM, Holloszy JO. Loss of skeletal muscle mass with aging: effect on glucose tolerance. J Gerontol A Biol Sci Med Sci. 1995; 50:68-72. [PubMed: 7493222]

17. Broughton DL, Taylor R. Deterioration of glucose tolerance with aging: the role of insulin resistance. Age Ageing. 1991; 20:221-225. [PubMed: 1853796]

18. Expert Committee on the Diagnosis, Classification of Diabetes Mellitus. Report of the expert committee on the diagnosis and classification of diabetes mellitus. Diabetes Care. 1999; 22:S5S19.

19. Reeds PJ, Fjeld CR, Jahoor F. Do the differences between the amino acid compositions of acutephase and muscle proteins have a bearing on nitrogen loss in traumatic states? J Nutr. 1994; 124:906-910. [PubMed: 7515956]

20. Wolfe, RR. Principle and practice of kinetic analysis. New York: Wiley-Liss; 1992. Appendix A: laboratory methods. In: Radioactive and stable isotope tracers in biomedicine; p. 417-438.

21. Biolo G, Fleming RY, Maggi SP, Wolfe RR. Transmembrane transport and intracellular kinetics of amino acids in human skeletal muscle. Am J Physiol. 1995; 268:E75-E84. [PubMed: 7840186]

22. Calder AG, Anderson SE, Grant I, McNurlan MA, Garlick PJ. The determination of low d5phenylalanine enrichment (0:002-0.09 atom percent excess), after conversion to phenylethylamine, in relation to protein turnover studies by gas chromatography/electron ionization mass spectrometry. Rapid Commun Mass Spectrom. 1992; 6:421-424. [PubMed: 1638043]

23. Jorfeldt L, Juhlin-Dannfelt A. The influence of ethanol on splanchnic and skeletal muscle metabolism in man. Metabolism. 1978; 27:97-106. [PubMed: 619229]

24. Jorfeldt L, Wahren J. Leg blood flow during exercise in man. Clin Sci. 1971; 41:459-473. [PubMed: 4941665]

25. Chinkes DL, Rosenblatt J, Wolfe RR. Assessment of the mathematical issues involved in measuring the fractional synthesis rate of protein using the flooding dose technique. Clin Sci. 1993; 84:177-183. [PubMed: 8382583] 
26. Wolfe, RR. Principle and practice of kinetic analysis. New York: Wiley-Liss; 1992. Calculation of substrate kinetics: single pool model. In: Radioactive and stable isotope tracers in biomedicine; $\mathrm{p}$. 119-144.

27. Bennet WM, Connacher AA, Scrimgeour CM, Jung RT, Rennie MJ. Euglycemic hyperinsulinemia augments amino acid uptake by leg tissues during hyperaminoacidemia. Am J Physiol. 1990; 259:E185-E194. [PubMed: 2166435]

28. Biolo G, Tipton KD, Klein S, Wolfe RR. An abundant supply of amino acids enhances the metabolic effect of exercise on muscle protein. Am J Physiol. 1997; 273:E122-E129. [PubMed: 9252488]

29. Tipton KD, Gurkin BE, Matin S, Wolfe RR. Nonessential amino acids are not necessary to stimulate net muscle protein synthesis in healthy volunteers. J Nutr Biochem. 1999; 10:89-95. [PubMed: 15539275]

30. Fryburg DA, Gelfand RA, Barrett EJ. GH acutely stimulates forearm muscle protein synthesis in normal humans. Am J Physiol. 1991; 260:E499-E504. [PubMed: 2003602]

31. Carraro F, Rosenblatt J, Wolfe RR. Isotopic determination of fibronectin synthesis in humans. Metabolism. 1991; 40:553-561. [PubMed: 1865818]

32. Yarasheski KE, Campbell JA, Smith K, Rennie MJ, Holloszy JO, Bier DM. Effect of GH and resistance exercise on muscle growth in young men. Am J Physiol. 1992; 262:E261-E267. [PubMed: 1550219]

33. Copeland KC, Nair KS. Acute GH effects on amino acid and lipid metabolism. J Clin Endocrinol Metab. 1994; 78:1040-1047. [PubMed: 8175957]

34. Corpas E, Harman SM, Blackman MR. Human GH and human aging. Endocr Rev. 1993; 14:2039. [PubMed: 8491152]

35. Toogood AA, Shalet SM. Ageing and GH status. Bailliere Clin Endocrinol Metab. 1998; 12:281296.

36. Baron AD, Steinberg HO, Chaker H, Leaming R, Johnson A, Brechtel G. Insulin-mediated skeletal muscle vasodilation contributes to both insulin sensitivity and responsiveness in lean humans. J Clin Invest. 1995; 96:786-792. [PubMed: 7635973]

37. Tack CJ, Schefman AE, Willems JL, Thien T, Lutterman JA, Smits P. Direct vasodilator effects of physiological hyperinsulinaemia in human skeletal muscle. Eur J Clin Invest. 1996; 26:772-778. [PubMed: 8889439]

38. Utriainen T, Malmstrom R, Makimattila S, Yki-Jarvinen H. Methodological aspects, dose-response characteristics and causes of interindividual variation in insulin stimulation of limb blood flow in normal subjects. Diabetologia. 1995; 38:555-564. [PubMed: 7489838]

39. Meneilly GS, Elliot T, Bryer-Ash M, Floras JS. Insulin-mediated increase in blood flow is impaired in the elderly. J Clin Endocrinol Metab. 1995; 80:1899-1903. [PubMed: 7775638]

40. Laakso M, Edelman SV, Brechtel G, Baron AD. Impaired insulin-mediated skeletal muscle blood flow in patients with NIDDM. Diabetes. 1992; 41:1076-1083. [PubMed: 1499861]

41. Tack CJ, Ong MK, Lutterman JA, Smits P. Insulin-induced vasodilatation and endothelial function in obesity/insulin resistance. Effects of troglitazone. Diabetologia. 1998; 41:569-576. [PubMed: 9628275]

42. Cusi K, Maezono K, Osman A, et al. Insulin resistance differentially affects the PI 3-kinase- and MAP kinase-mediated signaling in human muscle. J Clin Invest. 2000; 105:311-320. [PubMed: 10675357]

43. Kimball SR, Horetsky RL, Jefferson LS. Signal transduction pathways involved in the regulation of protein synthesis by insulin in L6 myoblasts. Am J Physiol. 1998; 274:E221-E228.

44. Svanberg E, Jefferson LS, Lundholm K, Kimball SR. Postprandial stimulation of muscle protein synthesis is independent of changes in insulin. Am J Physiol. 1997; 272:E841-E847. [PubMed: 9176184]

45. Hara K, Yonezawa K, Weng QP, Kozlowski MT, Belham C, Avruch J. Amino acid sufficiency and mTOR regulate p70 S6 kinase and eIF-4E BP1 through a common effector mechanism. J Biol Chem. 1998; 273:14484-14494. [PubMed: 9603962] 
46. Anthony JC, Anthony TG, Kimball SR, Vary TC, Jefferson LS. Orally administered leucine stimulates protein synthesis in skeletal muscle of postabsorptive rats in association with increased eIF4F formation. J Nutr. 2000; 130:139-145. [PubMed: 10720160]

47. Iiboshi Y, Papst PJ, Kawasome H, et al. Amino acid-dependent control of p70(s6k). Involvement of tRNA aminoacylation in the regulation. J Biol Chem. 1999; 274:1092-1099. [PubMed: 9873056]

48. Yarasheski KE, Zachwieja JJ, Bier DM. Acute effects of resistance exercise on muscle protein synthesis rate in young and elderly men and women. Am J Physiol. 1993; 265:E210-E214. [PubMed: 8368290]

49. Welle S, Thornton C, Jozefowicz R, Statt M. Myofibrillar protein synthesis in young and old men. Am J Physiol. 1993; 264:E693-E698. [PubMed: 8498491]

50. Welle S, Thornton C, Statt M. Myofibrillar protein synthesis in young and old human subjects after three months of resistance training. Am J Physiol. 1995; 268:E422-E427. [PubMed: 7900788]

51. Balagopal P, Rooyackers OE, Adey DB, Ades PA, Nair KS. Effects of aging on in vivo synthesis of skeletal muscle myosin heavy-chain and sarcoplasmic protein in humans. Am J Physiol. 1997; 273:E790-E800. [PubMed: 9357810]

52. Yarasheski KE, Pak-Loduca J, Hasten DL, et al. Resistance exercise training increases mixed muscle protein synthesis rate in frail women and men $\geq 76$ yr old. Am J Physiol. 1999; 277:E118E125. [PubMed: 10409135] 


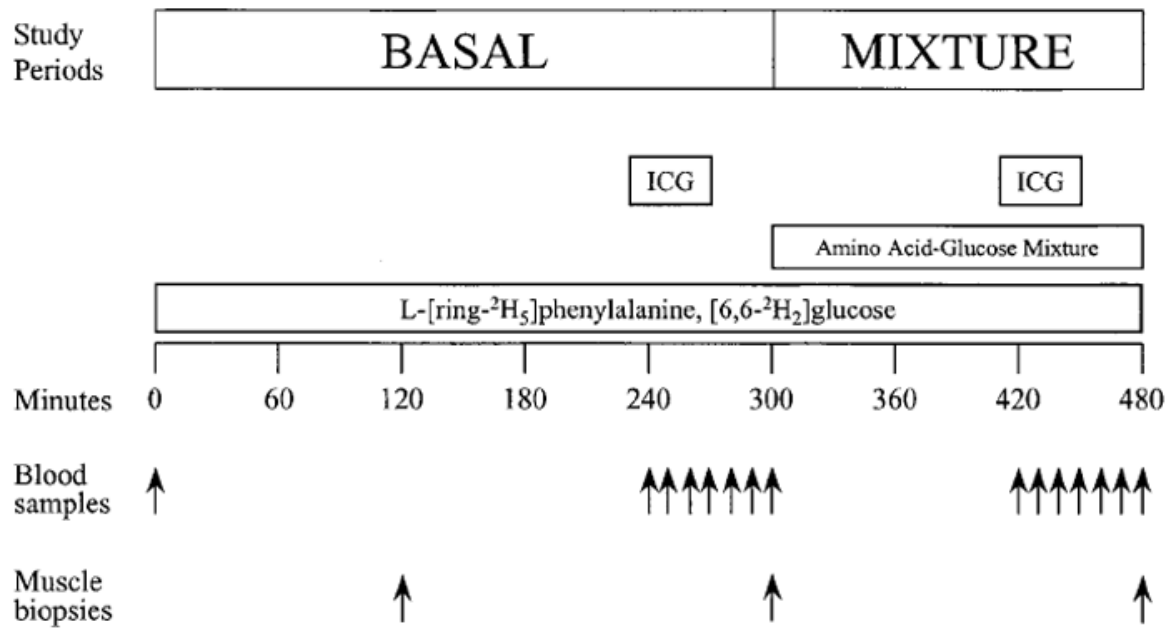

Fig. 1.

Study design. See text for details. 


\section{PHENYLALANINE ENRICHMENTS}

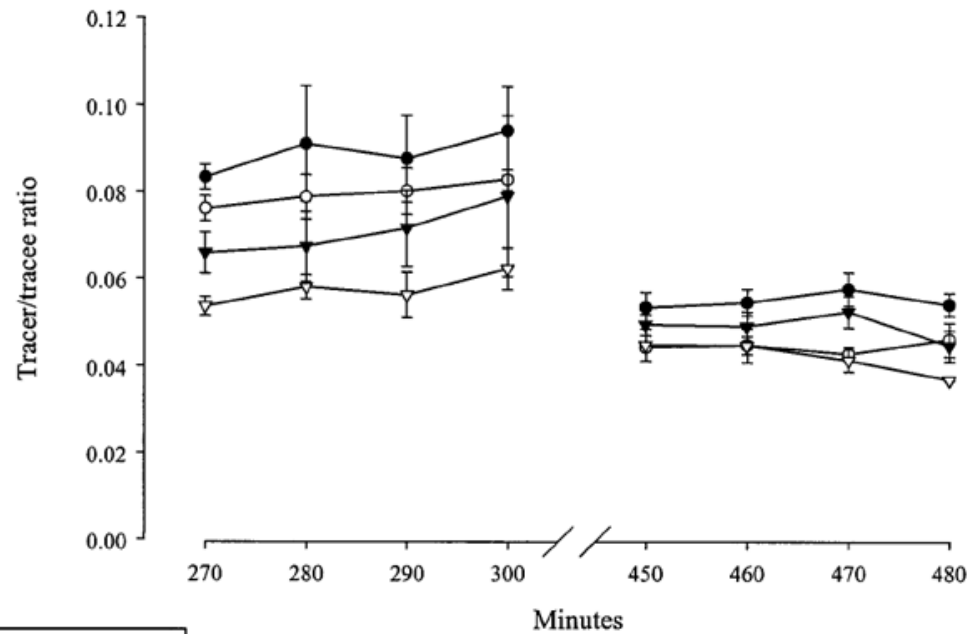

O Artery Young

- Artery Elderly

$\nabla$ Vein Young

$\boldsymbol{\nabla}$ Vein Elderly

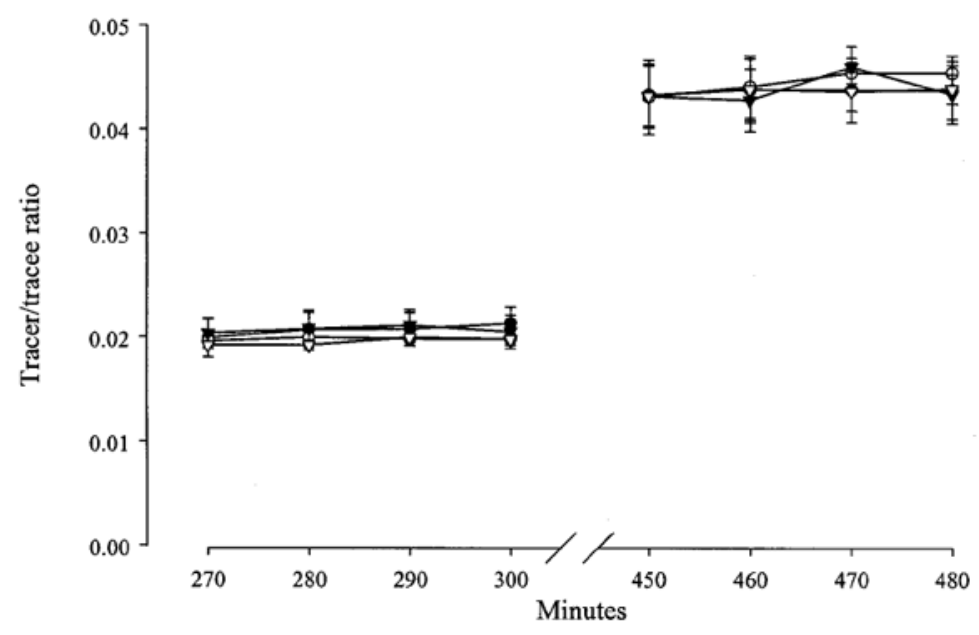

Fig. 2.

Phenylalanine and glucose enrichments. Time course of phenylalanine and glucose enrichments in the femoral artery and vein in healthy young (30 $\pm 3 \mathrm{yr})$ and elderly (72 \pm 1 yr) subjects in the basal state (270-300 min) and during the intake of an amino acid-glucose mixture (450-480 min). The enrichments were given at steady state during both sampling periods. Values are the mean \pm SE. 


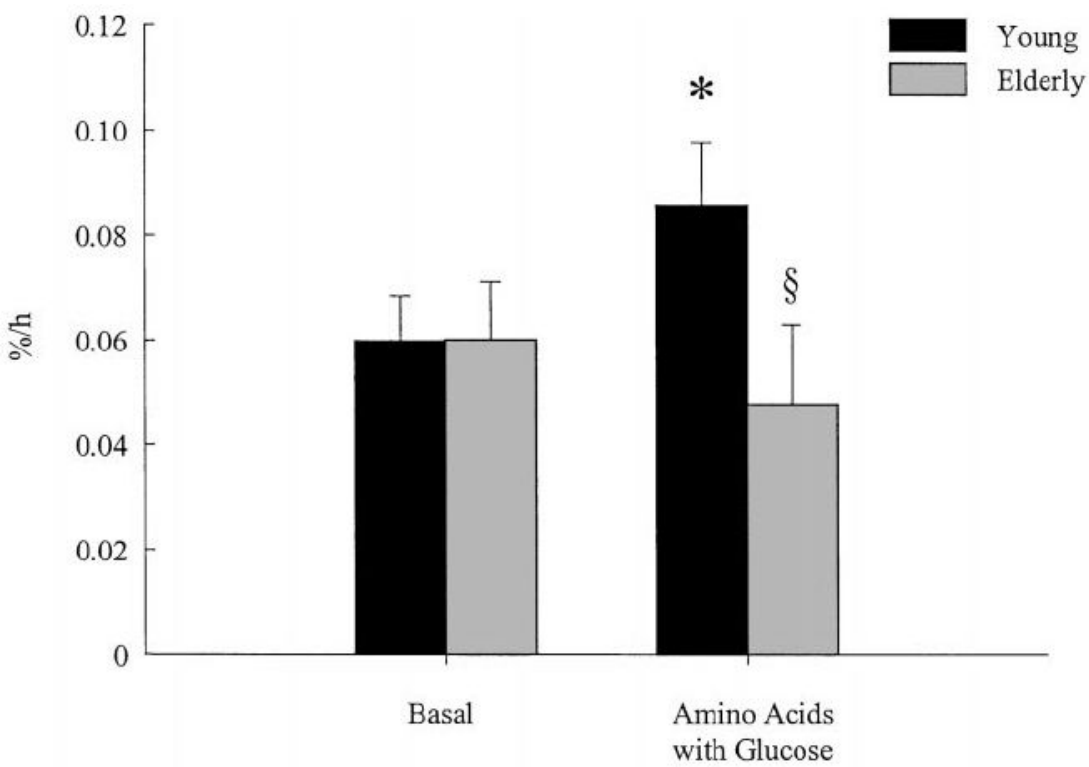

Fig. 3.

Muscle protein synthesis. The FSR of muscle proteins in healthy young ( $30 \pm 3 \mathrm{yr}$ ) and elderly ( $72 \pm 1 \mathrm{yr}$ ) subjects in the basal state and during the intake of an amino acid-glucose mixture. Values are the mean \pm SE. $*, P<0.01 v s$. basal; $\S, P<0.05 v s$. young. 


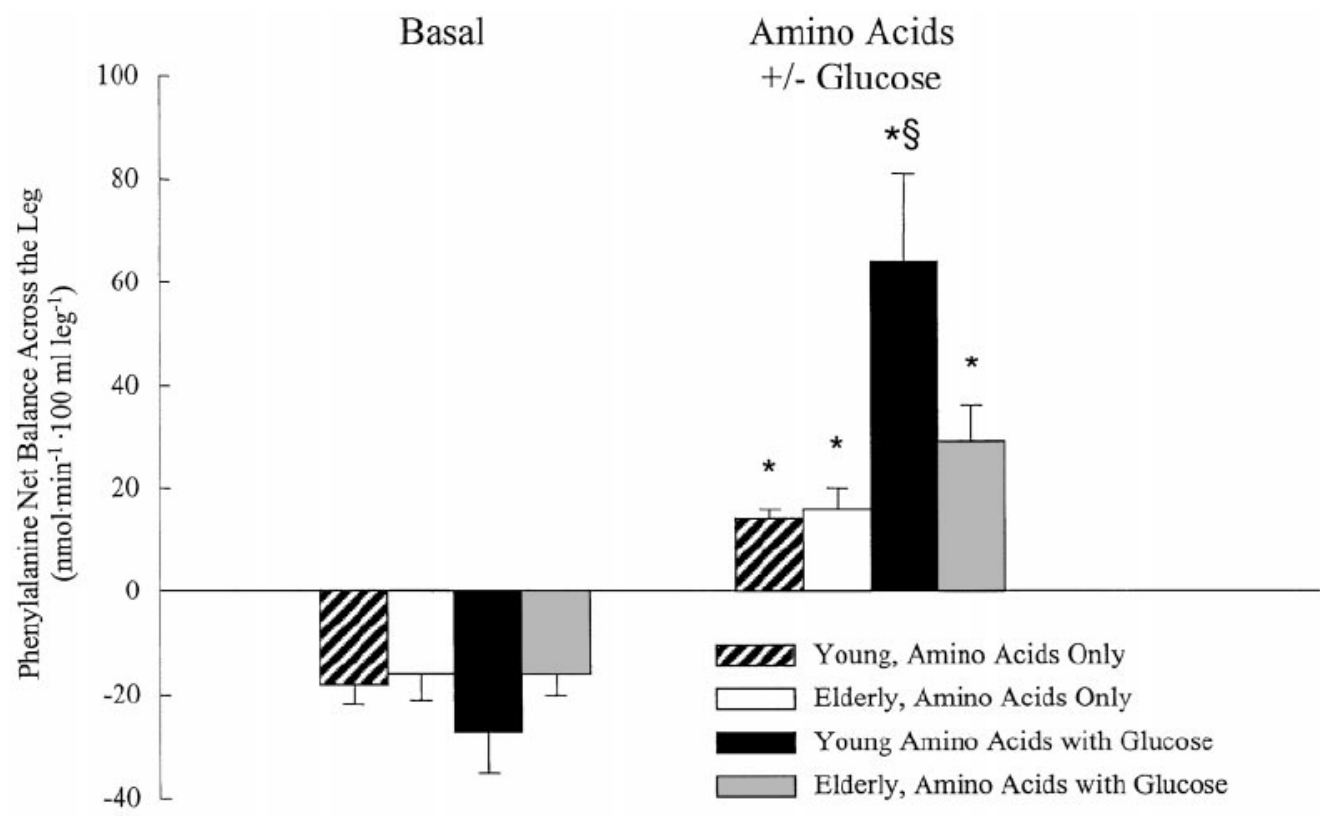

Fig. 4.

Comparison of the effects of the amino acid-glucose supplement (present study) vs. the same amount of amino acids alone (14) on muscle protein anabolism in young and elderly subjects. Muscle protein anabolism was measured as phenylalanine net balance across the leg in two comparable groups of young (present study: $\mathrm{n}=5,30 \pm 3$ yr; from Ref. 14: $\mathrm{n}=7$, $30 \pm 2 \mathrm{yr}$ ) and elderly subjects (present study: $\mathrm{n}=5,72 \pm 1 \mathrm{yr}$; from Ref. $14, \mathrm{n}=8,71 \pm 2$ $\mathrm{yr}$ ) in the basal state, and during the oral intake of the same amount of a mixed amino acid supplement with or without glucose. Phenylalanine net balance across the leg increased significantly during oral supplementation in all groups. However, compared with amino acids alone the addition of glucose to the supplement induced a significantly higher response in the young, whereas it did not add any benefit in the elderly. Values are the mean \pm SE. *, $P<0.01$ vs. basal; $\S, P<0.05$ vs. others. 


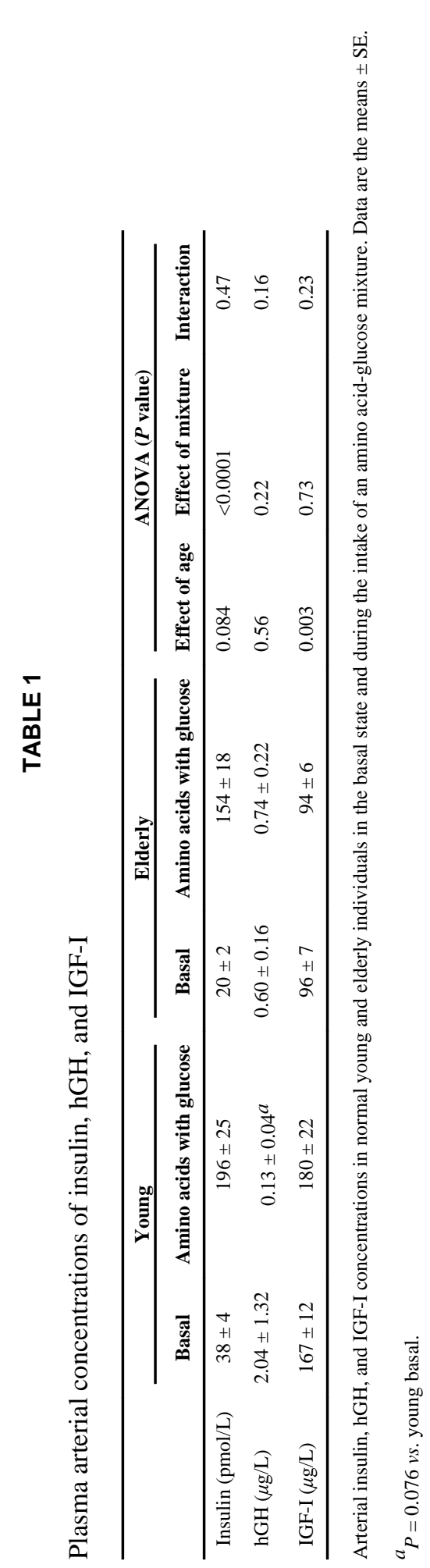

J Clin Endocrinol Metab. Author manuscript; available in PMC 2011 October 13. 
TABLE 2

Arterial amino acid concentrations

\begin{tabular}{|c|c|c|c|c|}
\hline & \multicolumn{2}{|r|}{ Young } & \multicolumn{2}{|r|}{ Elderly } \\
\hline & Basal & Amino acids with glucose & Basal & Amino acids with glucose \\
\hline \multicolumn{5}{|c|}{ Essential amino acids $(\mu \mathrm{mol} / \mathrm{L})$} \\
\hline Isoleucine & $40 \pm 3$ & $105 \pm 10^{a}$ & $40 \pm 2$ & $104 \pm 6^{a}$ \\
\hline Leucine & $167 \pm 21$ & $452 \pm 65^{a}$ & $131 \pm 12$ & $347 \pm 46^{a}$ \\
\hline Lysine & $172 \pm 15$ & $366 \pm 29^{a}$ & $166 \pm 15$ & $301 \pm 18^{a}$ \\
\hline Methionine & $8 \pm 1$ & $19 \pm 2^{a}$ & $9 \pm 1$ & $20 \pm 3^{a}$ \\
\hline Phenylalanine & $60 \pm 2$ & $133 \pm 8^{a}$ & $66 \pm 2$ & $138 \pm 9^{a}$ \\
\hline Threonine & $94 \pm 10$ & $177 \pm 19^{a}$ & $54 \pm 7$ & $141 \pm 23^{a}$ \\
\hline Tryptophan & $37 \pm 2$ & $54 \pm 3$ & $47 \pm 7$ & $101 \pm 5^{a}$ \\
\hline Valine & $124 \pm 6$ & $210 \pm 38^{a}$ & $119 \pm 9$ & $237 \pm 26^{a}$ \\
\hline \multicolumn{5}{|c|}{ Nonessential amino acids $(\mu \mathrm{mol} / \mathrm{L})$} \\
\hline Alanine & $303 \pm 29$ & $415 \pm 27^{a}$ & $246 \pm 36$ & $391 \pm 34^{a}$ \\
\hline Arginine & $109 \pm 15$ & $262 \pm 37^{a}$ & $124 \pm 7$ & $203 \pm 17^{a}$ \\
\hline Asparagine & $16 \pm 2$ & $79 \pm 12^{a}$ & $18 \pm 2$ & $49 \pm 8^{a, c}$ \\
\hline Aspartate & $19 \pm 2$ & $30 \pm 4^{a}$ & $26 \pm 2$ & $32 \pm 3^{a}$ \\
\hline Glutamine & $596 \pm 60$ & $684 \pm 65^{a}$ & $611 \pm 43$ & $677 \pm 53^{a}$ \\
\hline Glycine & $412 \pm 41$ & $556 \pm 42^{a}$ & $289 \pm 18$ & $475 \pm 142^{a}$ \\
\hline Histidine & $68 \pm 6$ & $117 \pm 9^{a}$ & $56 \pm 1$ & $80 \pm 6^{a, c}$ \\
\hline Serine & $124 \pm 8$ & $178 \pm 17^{a}$ & $66 \pm 7^{b}$ & $93 \pm 16^{a, b}$ \\
\hline Tyrosine & $36 \pm 4$ & $47 \pm 6$ & $43 \pm 4$ & $48 \pm 4$ \\
\hline
\end{tabular}

Arterial amino acid concentrations in normal young and elderly individuals in the basal state and during the intake of an amino acid-glucose mixture. Data are the means \pm SEM.

$a_{P<0.05 \text { vs. basal. }}$

${ }^{b} P<0.01 v s$. young.

${ }^{c} P<0.02 v s$. young within amino acids with glucose. 


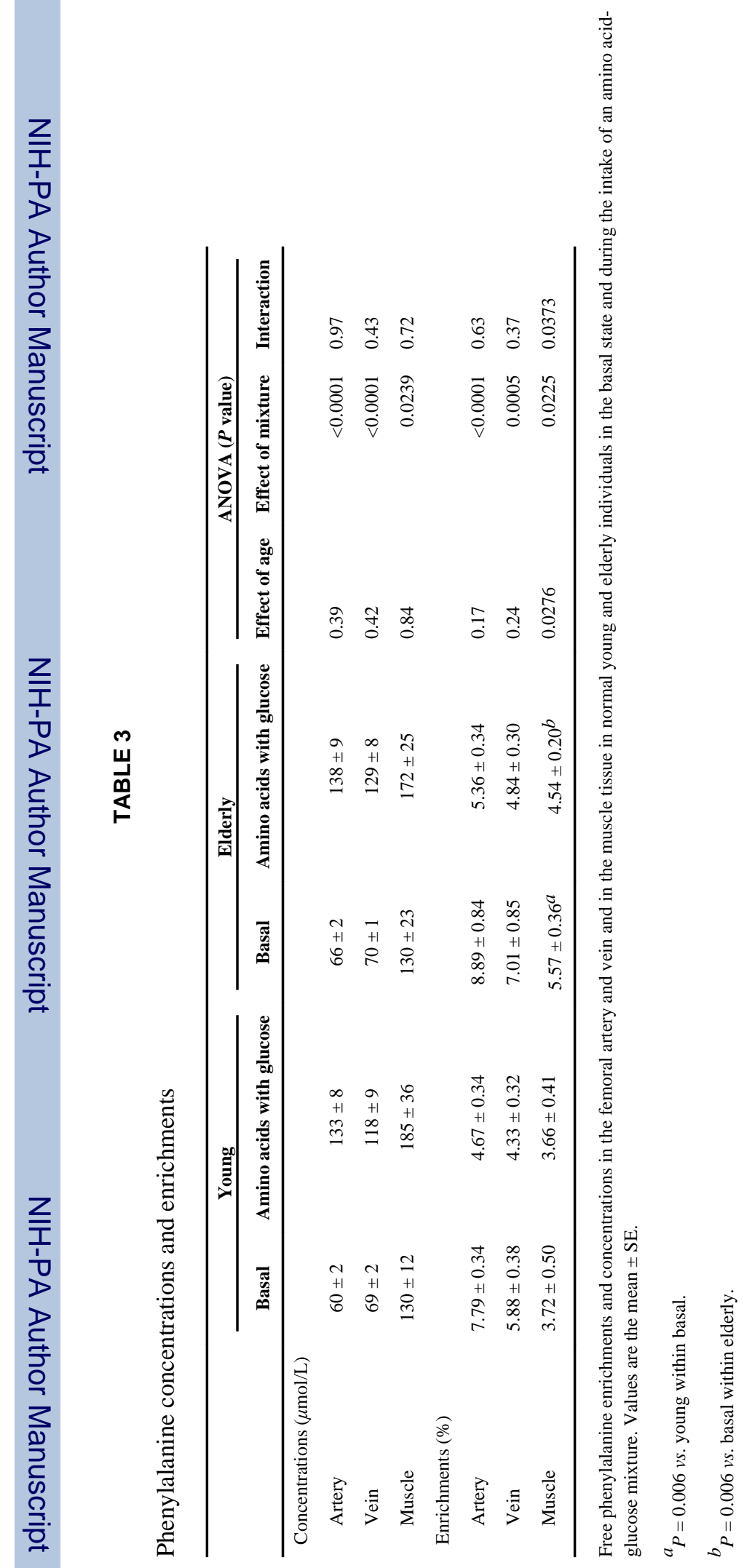

J Clin Endocrinol Metab. Author manuscript; available in PMC 2011 October 13. 


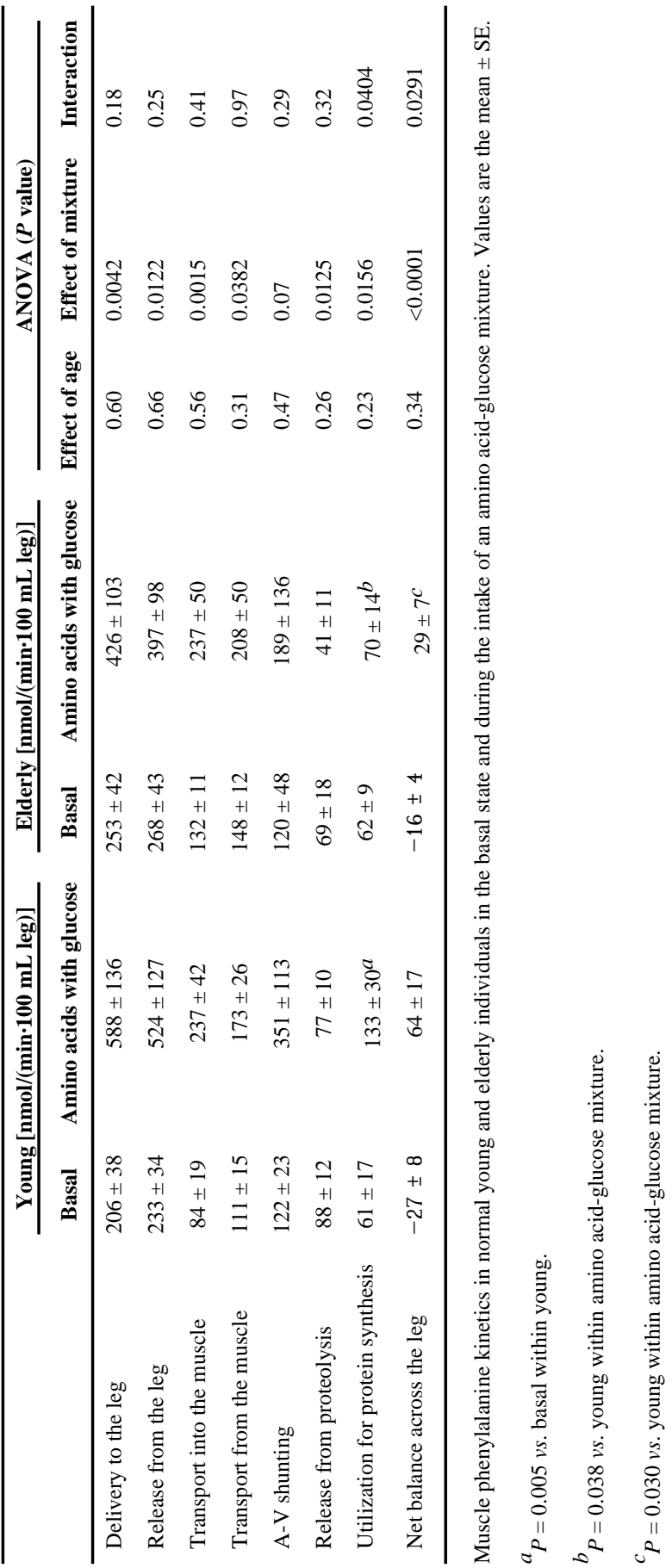




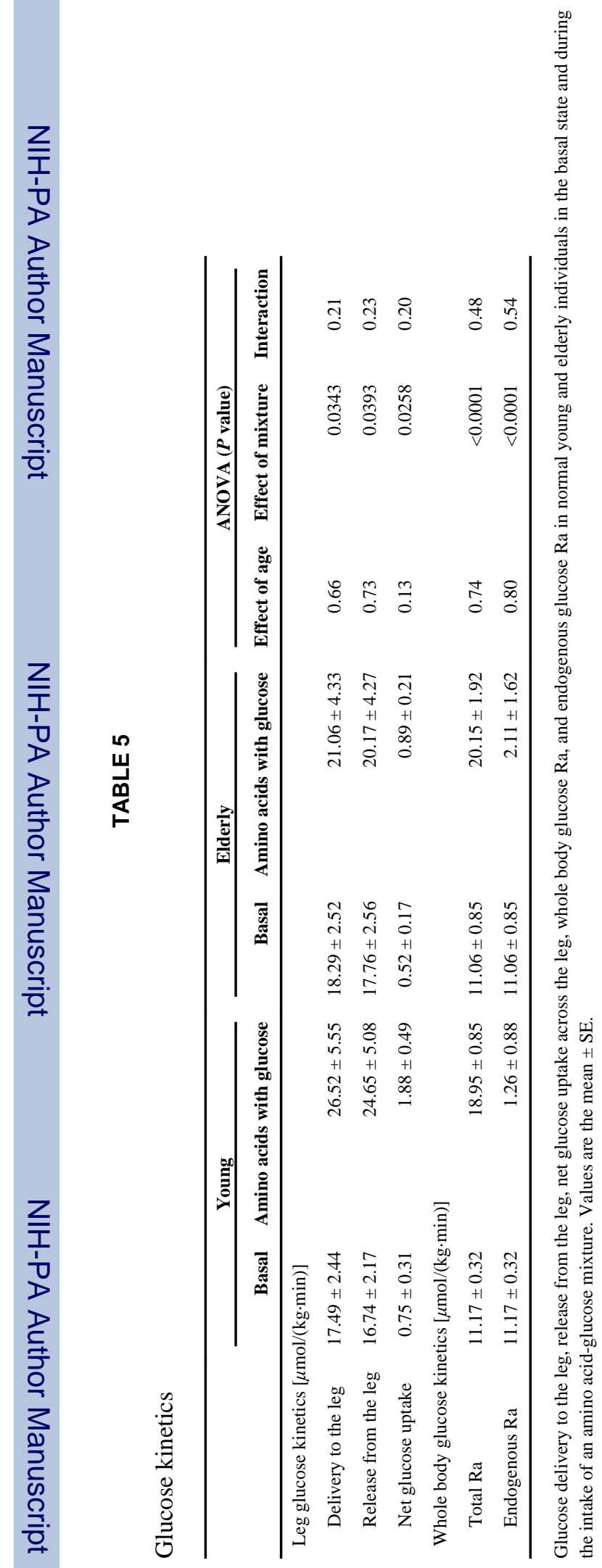

J Clin Endocrinol Metab. Author manuscript; available in PMC 2011 October 13. 